\title{
EFFECT OF OWNERSHIP STRUCTURE ON FINANCIAL STATEMENT FRAUD LIKELIHOOD OF LISTED CONGLOMERATE COMPANIES IN NIGERIA
}

\author{
USMAN Tanimu Gadi ${ }^{1}$, AKPAN Ekpeyo Danson ${ }^{1}$, LUKA Habiba Tessy ${ }^{2}$ and \\ ABOLUGBE, K. E. ${ }^{1}$ \\ ${ }^{1}$ Department of Accounting Nasarawa State University, Keffi \\ ${ }^{2}$ Department of Business Education, School of Secondary Education, Vocational and Technical, \\ Education Kaduna State College of Education, Gidan Waya \\ DOI: 10.46609/IJSSER.2020.v05i10.009 URL: https://doi.org/10.46609/IJSSER.2020.v05i10.009
}

\begin{abstract}
The study adopts longitudinal research design to examined effect of ownership structure on financial statement fraud prediction of listed conglomerate companies in Nigeria from 20102019. The ownership structure variables of managerial ownership, institutional ownership and foreign ownership were regressed against financial statement fraud probability using the Beneish $\mathrm{M}$-score. The result indicates that ownership structure can significantly improve detection of financial statement fraud likelihood in listed conglomerate companies in Nigeria. As managerial ownership has a significant effect on the detection of financial statement fraud likelihood, while institutional ownership and foreign ownership has no significant effect detection of financial statement fraud likelihood in listed conglomerate companies in Nigeria. Arising from the findings, the study recommendations that the structure of organization ownership should have managers and board members with significant stake in the business as it might facilitate effective monitoring of organization activities thereby, minimizing the level of fraudulent financial activities in the organization. Also, the organization ownership structure should also include active institutional investors or their representatives for proper oversight and monitoring of the organization activities. Finally, foreign investors should take active measures in participating or monitoring the organization activities thereby, minimizing the likelihood of fraudulent financial practices.
\end{abstract}

Keywords: Ownership Structure, Financial Statement Fraud Likelihood, Beneish M-Score 
International Journal of Social Science and Economic Research

ISSN: 2455-8834

Volume:05, Issue:10 "October 2020"

\section{INTRODUCTION}

Increase in fraud in the financial statements in the world has led many to speculate that management had committed fraud in the annual statements (Skousen \& Wright, 2006). Recently, financial accounting fraud detection has come into limelight due to the upsurge in financial frauds and white-collar crimes witnessed in the competitive economic scenario. In the last decade, high profile financial frauds committed by large companies in both developed and developing countries were discovered and reported, such as Enron, Lucent, WorldCom, Parmalat, YGX, SK Global, Satyam, Harris Scarfe, HIH and also the case of Cadbury Nigeria PLC (Lalit \& Virender, 2012). With a huge increase in accounting fraud witnessed, the need for efficient financial accounting fraud detection has gained considerable thrust from the investors, academic researchers, media, the financial community and regulators.

Among all the frauds, financial statement frauds are the costliest, regarding both the amount deceived compared to other frauds and their consequences. In fact, the detection of a financial statement fraud implies the decline of the firm value on the market and the loss of revenues for the company itself. Moreover, the whole market will suffer the reaction of the investors who will start being less trustful towards the market and, as a consequence, the companies will have more difficulties in obtaining the financial resources needed to develop or can access to these financial resources only at a higher cost (Lev, 2003).

Ownership structure is an internal control system exercise over a firm management team (Gonzalez \& Garcia-Meca, 2013). It is the distribution of equity with regard to votes and capital, but also by the identity of the equity owners. Gonzalez and Garcia-Meca (2013) are of the view that, apart from other firm level factors which influence financial statement reporting, firm's board formation and composition structure could also provide an opportunistic platform for managers to engage in behaviours that are self-serving thereby, reporting financial data without any sense of fraud.

Ownership structures play a central role in determining the extent to which the interests of owners and managers are aligned. Ownership structure also influence a firm's strategies, with higher internal equity fostering less risky acquisitions but large shareholders and certain institutional owners pressing for higher risk acquisitions. Firms may be owned by a diverse mix of different types of investors. These investors become owners in firms to accomplish financial objectives. Scholars have demonstrated that owners shape the incentives of managers to make competitive decisions (Yeo, 2012). Therefore, the role of owners on the financial statement fraud likelihood is important.

Though studies exist on the effect of ownership structure on financial statement fraud likelihood such as Andri and Muhammad (2013); Ines, Anis and Anis (2013); Luiss (2010); Waidi and Johnson (2016). Most of the studies were done in the developed nations with less literature in 


\section{International Journal of Social Science and Economic Research}

ISSN: $2455-8834$

Volume:05, Issue:10 "October 2020"

Nigeria. Also, Waidi and Johnson (2016), Aliyu and Ishaq (2015), Bala and Ibrahim (2016), Senmila and Elijah (2012) were carried out using banking sector and oil marketing companies with no literature in Nigeria on Conglomerates Companies.

Also, most of the studies do not reflect the current realities between ownership structure and financial statement fraud likelihood because the scope of the studies is not up to the current period. Thus, their findings cannot be meaningful in taking decision by various stakeholders of the companies. Hence, this study is necessary to fill this gap in literatures.

Further, Hamilton and Justin (2012) used quoted companies in Nigeria with focused on primary data which can be subjective. Therefore, respondents might not be truthful in their responses since financial statement fraud likelihood can be measure using secondary method, this study considered Beneish M-score as an appropriate tool to measure fraud likelihood of conglomerates companies in Nigeria as against other studies. Therefore, this study examined effect of ownership structure on financial statement fraud likelihood of listed Conglomerates companies in Nigeria. The following hypotheses were tested:

Ho1: Foreign ownership has no significant effect on financial statement fraud likelihood of Conglomerates companies in Nigeria.

Ho2: Institutional ownership has no significant effect on financial statement fraud likelihood of Conglomerates companies in Nigeria.

Ho3: Managerial ownership has no significant effect on financial statement fraud likelihood of Conglomerates companies in Nigeria.

The study is structured thus: section one covers the introduction, section two covers the literature review while section three covers the methodology used in the study. Furthermore, result and discussion was carried out in section four while section five gives the conclusion and recommendations.

\section{LITERATURE REVIEW}

\section{Concept of Ownership Structure}

The ownership structure is defined as the distribution of equity with regard to votes and capital as well as the identity of the equity owners. These structures are of Major importance in corporate governance because they determine the incentives of managers and thereby the economic efficiency of the corporations they manage (Jensen \& Meckling, 1976). Ownership structures are also characterised by the separation of voting rights from cash flow rights where control rights (or voting rights) of the largest owner were often generally greater than the 


\section{International Journal of Social Science and Economic Research}

ISSN: $2455-8834$

Volume:05, Issue:10 "October 2020"

corresponding cash flow rights. Higher voting rights may give rise to serious agency problems, and are often associated with pyramid ownership structures, and crossholding. Such situations are associated with an over-reliance on debt, due to large shareholders being unwilling to dilute their ownership. This is known as non-dilution of entrenchment (Claessens \& Fan 2002).

Ownership structure could be defined as the means of control over a business enterprise and being able to dictate its functioning and operations (Yeo, 2012). Zhuang (1999) argue that ownership structure is one of the most important factors in shaping the corporate governance system of any country. This is because it determines the nature of the agency problem. That is, whether the dominant conflict is between managers and shareholders, or between controlling and minority shareholders. Zhuang identified two important aspects of corporate ownership structure as concentration and composition. According to him, the degree of ownership concentration in a firm determines how power is distributed between its shareholders and managers. When ownership is dispersed, shareholding control tends to be weak because of poor shareholder monitoring the author affirms.

Managerial ownership represents the interest of managers in the equity shareholding of a firm. The reason behind the rise of this Corporate governance variable is rooted in the agency theory, which assumes that managers' equity holdings encourages them to act in a way that maximizes the value of the firm (Aliyu \& Ishaq, 2015). According to Waldi and Johnson (2016), managerial ownership is a situation where insiders or managers of the firm act as shareholders if they acquire a considerable portion of the entity's shares, and this is deemed to be useful in reducing agency conflicts and aligning the interests of management and shareholders.

Foreign and local investors are likely to invest in companies for which timely information is more easily available (Ahearne, Griever \& Warnock 2000). Timely financial statements assist foreign ownership to preserve their investment by monitoring the management's performance and making efficient decision as soon as possible.

\section{Concept of Financial Statement Fraud}

According to Robertson (1976), fraud is any deception practiced to cheat or deceive another to his own detriment or to the detriment of any other, or to cause another loss or injury, while the perpetrator has a clear knowledge of his deliberate falsehood, deceptions or advantage over the innocent and unsuspecting victim. Similarly, Stanley (1994) defined fraud as consisting of knowingly making material misrepresentations of facts, with the intent of inducing someone to believe the falsehood and act upon it, thus suffering a loss or damage.

Financial statement fraud exploits the information asymmetry that exists between different parties in a financial transaction. By combining the illusion of disclosure with false information, financial statement fraud increases this information asymmetry while appearing to minimize it (Black, 2006). Leap (2007) points out, accounting fraud may have either one of two objectives. 


\section{International Journal of Social Science and Economic Research}

ISSN: $2455-8834$

Volume:05, Issue:10 "October 2020"

First, fraudulent accounting techniques may be used to cover up the misappropriation or misapplication of funds. Company insiders who embezzle funds from the company may alter accounting ledgers and supporting documentation to conceal their deeds. Second, fraudulent financial statements may be issued by managers to mislead investors or regulators about the profitability and future prospects of an enterprise.

According to Wells (2011), financial Statement Fraud includes several modes, among others: Forgery, alteration, or manipulation of financial records, supporting documents or business transactions; Removal of deliberate on events, transactions, accounts, or other significant information as a source of financial statement presentation; Application of false and deliberate on the accounting principles, policies, and procedures used to measure, recognize, report and disclose economic events and business transactions; and, Removal of deliberate on the information that should be presented and disclosed regarding the principles and accounting policies used in the financial reporting (Rezaee, 2002).

The aforementioned relation between financial statement reliance and fraud risk assessment may be influenced by an investor's perception of the rate of fraudulent financial reporting because higher base rates can lead to higher predictions of an outcome (Manis, Dovalina, Avis \& Cardoze, 1980), higher perceived fraud rates should fuel investor concerns over the credibility of financial statement data. Prior accounting research shows that the credibility of information disclosed by management influences investors' actions (Jennings, 1987; Mercer, 2004). For investors who perceive a higher rate of fraud (lower credibility), given a level of financial statement reliance, one would expect fraud risk assessment to be a more important activity when making investment judgments (vs. investors who perceive a lower rate of fraud). One can therefore predict that the perceived frequency of fraud occurrence will positively moderate the positive relation between investor reliance on financial statement data and the importance they place on making a fraud risk assessment.

\section{Ownership Structure and Financial Statement Fraud Likelihood}

Riadi and Mita (2018) examined effect of ownership structure on the tendency of firms to conduct tunneling practices. The samples employed are companies listed on the Indonesia Stock Exchange from 2013 to 2015. The study found that concentrated family ownership and concentrated government ownership have a positive effect on firm tunneling practices, while concentrated institutional ownership and dispersed ownership have a negative effect. Concentrated family ownership has a significant positive effect on firms' tunneling practices, while concentrated government ownership, concentrated institutional ownership, and dispersed ownership have a significant negative effect on a firm's tunneling practices.

Hafiza and Susela (2012) studied the relationship between institutional ownership in Malaysia and the quality of reported earnings covering 1998 to 2006 . Using the accrual quality model to 


\section{International Journal of Social Science and Economic Research}

ISSN: $2455-8834$

Volume:05, Issue:10 "October 2020"

measure earnings quality, the study provides evidence that concentrated shareholdings, in the hands of institutional investors, afford greater incentives to closely monitor firms' activities. The results confirm the active monitoring hypothesis, which suggests that institutional investors are likely to actively monitor their investments due to the large amount of wealth they invested.

Farzin and Roshani (2012) assessed earnings management in Iran and the effect of discretionary accruals, as a proxy for earnings management, on future profitability. Also, the study considered the effect of firm size, ownership structure, audit quality and the proportion of independent board members on it using a sample of 167 firms in a 6-year financial period from 2004 to 2009. It was analyzed using fixed effect regression method. The results show that managers tend to use efficient earnings management in Iran and firm size, ownership structure, audit quality and the proportion of independent board members can influence on the type of earnings management.

Waidi and Johnson (2016) examined the relationship between Corporate Ownership Structure and Financial Reporting Quality among Deposit Money Banks in Nigeria. The paper analysed whether a firm's ownership structure (measured with three variables: managerial ownership, foreign ownership and institutional ownership) improves the quality of the financial reporting or not. Using a sample of all Deposit Money Banks listed on Nigeria Stock Exchange for nine years between 2005 and 2013, using Ordinary Least Square (OLS) Regression technique. It was found that discretionary accruals as a proxy for financial reporting quality is positively related to managerial ownership and relate negatively to institutional and foreign ownership. The study's result suggests that managerial ownership improve the quality of annual earnings by reducing the levels of financial reporting manipulation. The study may not have practical impact because it was conducted in 2016 but the scope covers 2005 to 2013 which means that there is time lag between 2013 and 2016. Therefore, Waldi and Johnson (2016) could have extend the period to 2015 as the scope of the study which may give more practical significance to the policy makers as well as the investors.

Beuselinck, Belen and Juan (2013) ascertained the role of foreign shareholders in improving the quality of accounting information provided by firms domiciled in poor institutional quality countries using a sample of firms from Portugal, Italy, Greece and Spain for the period 20022007. The study found that firm-level earnings quality is positively associated with foreign shareholdings. Also, the result shows that increases in foreign ownership from firms domiciled in countries with strong institutional quality lead to a subsequent increase in firm-level earnings quality, while the opposite is not true. Furthermore, improvement in earnings quality is more pronounced when consider the effect of institutional investors. Finally, we find that the results hold before and after the introduction of the International Financial Reporting Standards (IFRS) in 2005. Combined, these results are consistent with the institutional environment and the presence of foreign ownership having a higher impact on earnings quality than a mandatory switch to better reporting standards.

Tarjo and Nurul (2015) analyzed the ability of m-score Beneish in detecting financial fraud. This 


\section{International Journal of Social Science and Economic Research}

ISSN: $2455-8834$

Volume:05, Issue:10 "October 2020"

study data refers to companies that commit fraud according to the fraud Database of Sanctions of Issuer Cases Public Companies that was released by the Financial Services Authority in the period of 2001-2014. The results showed that overall Beneish m-score model was capable to detect financial fraud. Gross margin index, depreciation index, index of sales and general administrative burden and total accruals were all significant in detecting financial fraud. Sales index, asset quality index, and leverage index was statistically not significant in detecting financial fraud.

Hamilton and Justin (2012) ascertained the management of financial fraud in quoted companies in Nigeria employing a sample of 22 firms and Using the questionnaire and oral interviews as study instruments, data were obtained, and analyzed using simple percentages and frequency distribution tables. It was found that-: poor internal systems are the major cause of fraud in Nigeria organizations, Funds diversion is the commonest kind of fraud. Furthermore, most business organizations do not make fraud cases public. Also, young people within the age brackets of 31-40 years and polygamists recorded highest cases of involvement in fraudulent acts among the employees and the frequency of Males involvement in fraudulent act surpassed that of females. The study however concludes that even though fraud cannot be completely eliminated from our business life, its occurrence can be minimized through better internal control systems and by placing those personality types with the least propensity to commit fraud in sensitive and vulnerable positions.

Hamadi and Ines (2011) investigated the link between corporate financial statement fraud and Board of Directors on a sample of 64 Tunisian firms, with 32 fraud firms matched by 32 no fraud similar (control) companies. Since our dependent variable is binary (fraud versus no fraud), we use a logistic regression to explain how the probability of fraud can be determined by governance variables. The main results show that there is a significant difference in governance variables between fraudulent and control firms. It was also confirmed the importance of governance variables in explaining the probability of fraud since it was found that firms with a board of directors dominated by family members and with tenure of outside directors are more likely to commit fraud in financial statement.

Agency Theory: According to agency theory, separation of ownership and control leads to a divergence in the pursuit of managerial interests versus owners' interests (Jensen \& Meckling 1976), and thus monitoring managerial decisions becomes essential to assure that shareholders' interests are protected, and to ensure reliable and complete financial reporting. Corporate governance provides a set of constraints to reduce the agency costs originated by the nexus of contracts in the firm (Iturriaga \& Hoffmann, 2005) or a framework to ensure suppliers of corporate finance achieve a return on their investment (Shleifer \& Vishny, 1997). The role of the corporate governance structure in financial reporting is to ensure compliance with financial accounting system and to maintain the credibility of financial statements (Bushman \& Smith, 


\section{International Journal of Social Science and Economic Research}

ISSN: $2455-8834$

Volume:05, Issue:10 "October 2020"

2003). Thus, properly structured corporate governance mechanisms are expected to reduce fraud likelihood because they provide effective monitoring of management in the financial reporting process. Some studies have documented that the manager's incentive to manage earnings is limited by certain corporate governance mechanisms (Dechow, Sloan \& Sweeney, 1996; Jiambalvo, 1996).

The ownership structure of a firm is considered an important managers' monitoring mechanism, so it may have a monitoring role in constraining the occurrence of earnings management. Extant literature suggests that different ownership structures imply different incentives to control and monitor a firm's management (Morck, Shleifer \& Vishny, 1988; Shleifer \& Vishny, 1986). For example, ownership concentration has implications for the level of information asymmetry between managers and investors, and this influences the quality of earnings and managers' accounting choices (Donnelly \& Lynch, 2002; Fan \& Wong, 2002). The quality of earnings is also associated with different types of ownership. For example, management ownership could have a negative effect on earnings management (Warfield, Wild \& Wild, 1995) or a positive effect due to entrenchment or expropriation effects (Cheng \& Warfield, 2005). Other studies have also investigated whether institutional investors have an impact on earnings management (Cornett, Marcus \& Tehraniam, 2008; Ebrahim, 2007). To analyse whether a firm's ownership structure provides effective monitoring of earnings management, three types of ownership are considered: foreign concentration, institutional ownership and managerial ownership.

\section{METHODOLOGY}

This study adopts longitudinal research design because the study examined the effect of ownership structure on financial statement fraud likelihood from 2010-2019 which data cut across difference firms along several periods. The study focused on the conglomerates companies in Nigeria with the population of five listed companies on the Nigeria stock exchange as at 2019. All the companies will be use.

Secondary data is used in this study. Specifically, the study used financial statements. All the data was collected by review of annual reports of the companies. Therefore, foreign ownership, institutional ownership and managerial ownership is used as the measure of ownership structure and Beneish M-score as a measure for financial statement fraud likelihood in this study. Panel multiple regression were used for the analysis.

$\mathrm{OS}=\mathrm{f}(\mathrm{BMS})$

Ownership Structure $(\mathrm{OS})=$ FOW, INO and MGO Financial statement fraud $=$ BMS The linear regression equation: 
International Journal of Social Science and Economic Research

ISSN: 2455-8834

Volume:05, Issue:10 "October 2020"

$B M S i t=\alpha+\beta 1 F O W i t+\beta 2 I N O i t+\beta 3 M G O i t+e i t$

Where:

BMSit = Beneish M-score of firm $i$ at time $t$

$F O i t=$ Foreign ownership of firm $i$ at time $t$

INOit = Institutional ownership of firm $i$ at time $t$

$M G O i t=$ Managerial ownership of firm $i$ at time $t$

$\alpha=$ Constant Term

$\beta 1-\beta 3=$ Beta Coefficient

$e=$ error term

MEASUREMENT OF VARIABLES

\begin{tabular}{|l|l|}
\hline BMS & $\begin{array}{l}\text { M-score=4.84 + 0.920*DSRI + 0.528*GMI + } \\
0.404 * \mathrm{AQI}+0.892^{*} \mathrm{SGI}+0.115 * \mathrm{DEPI}-\end{array}$ \\
\hline \multirow{2}{*}{ Foreign ownership (FO) } & $\begin{array}{l}\text { Number of shares in firm } i \text { by institutions } \\
\text { domiciled in a country different from country } i \\
\text { where the firm is incorporated as a percentage of } \\
\text { the market capitalization of country } i\end{array}$ \\
\hline Institutional ownership (IO) & $\begin{array}{l}\text { Institutional ownership is measured by } \\
\text { dividing the natural logarithm of shares that } \\
\text { are held by the institutions to the gross number } \\
\text { of firm's shares. }\end{array}$ \\
\hline Managerial ownership (MGO) & $\begin{array}{l}\text { Percentage of Number of shares held by } \\
\text { managers as a proportion of the number of shares } \\
\text { outstanding (average across firms }\end{array}$ \\
\hline
\end{tabular}


International Journal of Social Science and Economic Research

ISSN: 2455-8834

Volume:05, Issue:10 "October 2020"

\section{RESULT AND DISCUSSION}

Table 1: Descriptive Statistics

\begin{tabular}{|l|c|c|c|}
\hline & FOW & INO & MGO \\
\hline Mean & 0.031926 & 0.039398 & 0.037420 \\
\hline Median & 0.024110 & 0.035860 & 0.032635 \\
\hline Maximum & 0.097660 & 0.093060 & 0.090490 \\
\hline Minimum & 0.001460 & 0.008960 & 0.002280 \\
\hline Std. Dev. & 0.028925 & 0.025324 & 0.027856 \\
\hline Skewwness & 0.788906 & 0.765322 & 0.438092 \\
\hline Kurtosis & 2.579418 & 2.526492 & 1.908694 \\
\hline Jarque-Bera & 5.554957 & 5.348086 & 4.080516 \\
\hline Probability & 0.062195 & 0.068973 & 0.129995 \\
\hline Sum & 1.596310 & 1.969880 & 1.871020 \\
\hline Sum Sq. Dev. & 0.040996 & 0.031423 & 0.038021 \\
\hline Observations & 50 & 50 & 50 \\
\hline
\end{tabular}

SOURCES: EVIEWS 10 OUTPUT, 2020

Table 1 indicates that Foreign Ownership (FOW) has an average value of 0.031926 with a standard deviation of 0.028925, and minimum and maximum values of 0.001460 and 0.097660 respectively. The standard deviation signifies that the data deviate from both sides of the mean value by 0.028925 .

Also, the result shows on the average that Institutional ownership has an average value of 0.039398 i.e. Institutional ownership is on the average $3.9 \%$ for listed conglomerate companies in Nigeria, with standard deviation of 0.025324 and minimum and maximum values of 0.008960 and 0.093060 respectively. The standard deviation signifies that the data deviate from both sides of the mean value by 0.025324 .

Further, the study indicates that the average Managerial ownership of listed conglomerate companies is $3.7 \%$, with standard deviation of 0.027856 and minimum and maximum values of 0.002280 and 0.090490 respectively. The standard deviation signifies that the data deviate from both sides of the mean value by 0.027856 .

\section{Correlation Analysis}

Table 2 represents a correlation matrix for the selected variables; The Pearson's correlation matrix shows that the degree of correlation between the independent variables is either low or moderate, which suggests the absence of multicollinearity between independent variables. Prior 
International Journal of Social Science and Economic Research

ISSN: 2455-8834

Volume:05, Issue:10 "October 2020"

testing the regression model, one had to check, first the absence of any correlation problem among variables, by means of Pearson correlation. A review of Table (2) indicate well that the entirety of correlation coefficients falls below the threshold of 0.8, the limit traced by Kennedy (1985). So, one may infer that our regression model introduced do not appear to demonstrate any present a serious correlation problem.

Table 2

\begin{tabular}{|c|c|c|c|c|c|}
\hline & BMS & FOW & INO & MGO & VIF \\
\hline BMS & 1.000000 & & & & \\
\hline FOW & -0.083268 & 1.000000 & & & 1.131928 \\
\hline INO & -0.024095 & 0.325725 & 1.000000 & & 1.148162 \\
\hline MGO & -0.350730 & -0.166414 & -0.203571 & 1.000000 & 1.055578 \\
\hline
\end{tabular}

SOURCES: EVIEWS 10 OUTPUT 2020

In addition, it has been discovered that the tolerance level relevant to all variables appears to be close to 1, testifying that no collinearity assumption is well confirmed. Besides on calculating the VIF values, the figures reveal that they prove to fall below the threshold of 10 with regard to all variables. These results allow us to confirm the absence of multi collinearity problem in concerning multiple regression models.

\section{Hausman Specification Test}

Because of the homogeneity of data used in this study, which assumes that fixed effects and random effects models are similar, Hausman test is performed to determine which of the two models is more efficient.

\section{Table 3: Hausman Specification Test \\ Correlated Random Effects - Hausman Test \\ Equation: Untitled \\ Test period random effects}

\begin{tabular}{lrrr}
\hline \hline Test Summary & $\begin{array}{r}\text { Chi-Sq. } \\
\text { Statistic }\end{array}$ & Chi-Sq. d.f. & Prob. \\
\hline \hline Period random & 1.516012 & 3 & 0.6786 \\
\hline \hline
\end{tabular}

SOURCES: EVIEWS 10 OUTPUT 2020

The Hausman specification test was conducted to choose between the fixed and random effect model. The 


\section{International Journal of Social Science and Economic Research}

ISSN: 2455-8834

Volume:05, Issue:10 "October 2020"

Hausman test specified the use of random effect model as against fixed effect model.

\section{Table 4: Regression Result}

Dependent Variable: BMS

Method: Panel EGLS (Period random effects)

Date: 08/26/20 Time: 14:26

Sample: 20102019

Periods included: 10

Cross-sections included: 5

Total panel (balanced) observations: 50

Swamy and Arora estimator of component variances

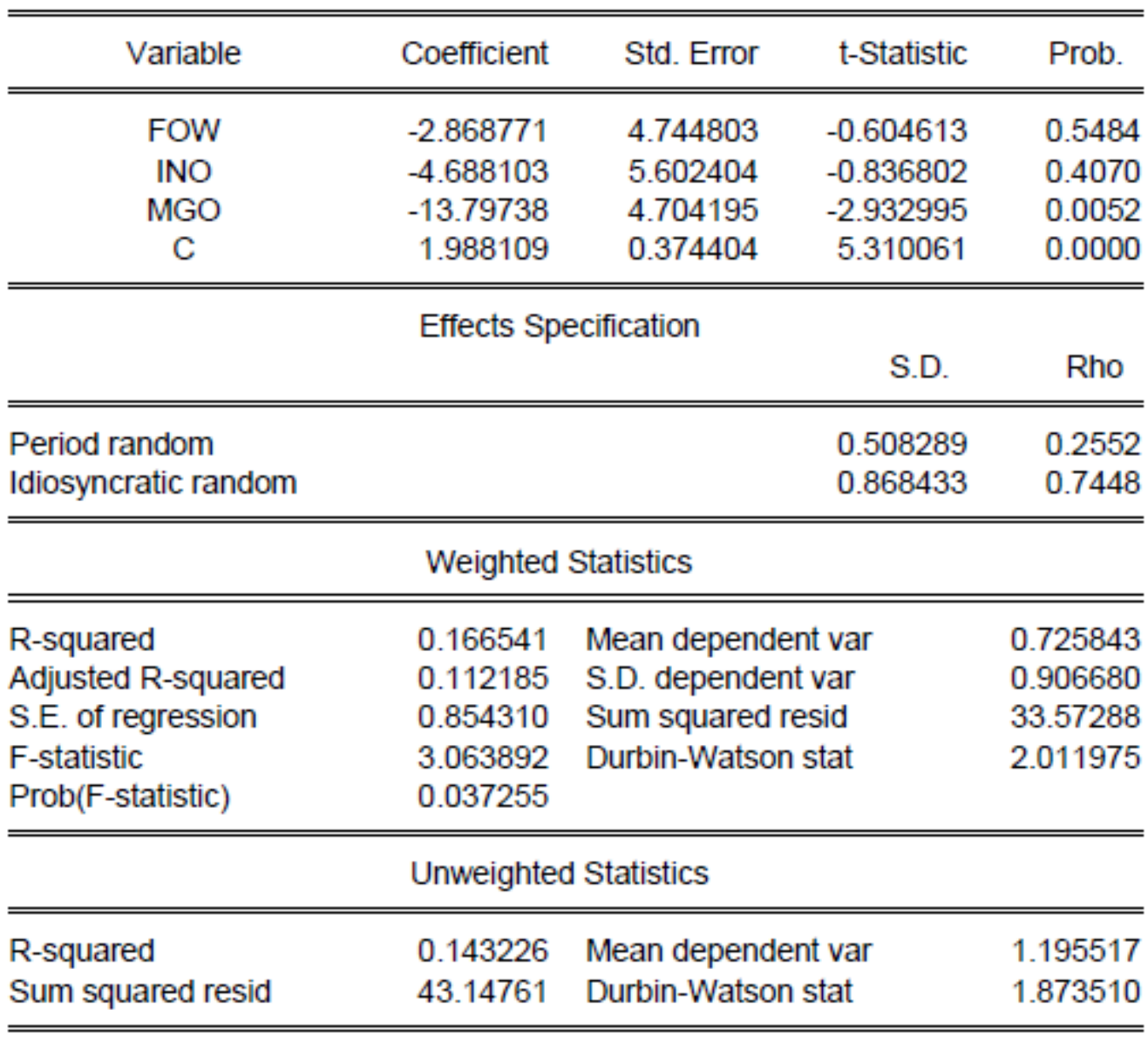

SOURCES: EVIEWS 10 OUTPUT 2020

The regression result shows the relationship between financial statement fraud likelihood and 


\section{International Journal of Social Science and Economic Research}

ISSN: $2455-8834$

Volume:05, Issue:10 "October 2020"

Ownership structure variables of (Foreign ownership, Institutional ownership and managerial ownership) of listed conglomerate Companies in Nigeria. The result shows an R-squared coefficient of 0.166541 indicating that about $16.7 \%$ of the variability in financial statement fraud likelihood is explained by foreign ownership, institutional ownership and managerial ownership of listed conglomerate Companies in Nigeria while the remaining $83.3 \%$ is explained by variables not captured in the study. The model is fit and appropriate with a $\mathrm{P}$ - value of 0.037255 .

From the result, managerial ownership (P-value, 0.0052) has a significant negative effect with financial statement fraud likelihood. Therefore, we fail to accept the null hypothesis. This implies that as managerial ownership increases in an organization the financial statement fraud likelihood decreases and vice-versa. The findings of this study align with that of Waidi and Johnson (2016) and Beuselinck, Belen and Juan (2013).

However, foreign ownership has negative insignificant effect with financial statement fraud likelihood. This implies that foreign ownership is not a factor that aid in detecting financial statement fraud probability. We therefore, fail to reject the null hypothesis. The findings of this study are not in agreement with that of Beuselinck, Belen and Juan (2013) and Farzin and Roshani (2012) but aligns with that of Waidi and Johnson (2016).

Similarly, institutional ownership has negative insignificant effect with financial statement fraud likelihood. This connotes that institutional ownership does not improve the ability to predict financial statement fraud likelihood. This finding is in consonance with that of Waidi and Johnson (2016) but disagrees with the findings of Hafiza and Susela (2012) and Farzin and Roshani (2012).

\section{CONCLUSION AND RECOMMENDATIONS}

The study considers the effect of ownership structure on financial statement fraud prediction of listed conglomerate companies in Nigeria. It is based on 50 firm's observations of listed conglomerate companies in Nigeria using Beneish M-score. The ownership structure variables of managerial ownership, institutional ownership and foreign ownership were regressed against financial statement fraud probability using the Beneish M-score. The result indicates that ownership structure can significantly improve detection of financial statement fraud likelihood in listed conglomerate companies in Nigeria. As managerial ownership has a significant effect on the detection of financial statement fraud likelihood, while institutional ownership and foreign ownership has no significant effect detection of financial statement fraud likelihood in listed conglomerate companies in Nigeria. Arising from the findings the following recommendations are made: 
International Journal of Social Science and Economic Research

ISSN: 2455-8834

Volume:05, Issue:10 "October 2020"

The structure of organization ownership should have managers and board members with significant stake in the business as it might facilitate effective monitoring of organization activities thereby, minimizing the level of fraudulent financial activities in the organization. The organization ownership structure should also include active institutional investors or their representatives for proper oversight and monitoring of the organization activities.

Finally, foreign investors should take active measures in participating or monitoring the organization activities thereby, minimizing the likelihood of fraudulent financial practices.

\section{REFERENCES}

Ahearne, A., Griever, W., \& Warnock, F. (2000). Information costs and home bias: An analysis of Us holdings of foreign equities. Mimeo, Federal reserve board.

Aliyu, S. K., \& Ishaq, A. S. (2015). Board characteristics, independent audit committee and financial reporting quality of Oil marketing firms: Evidence from Nigeria. Journal of Finance, Accounting and Management, 6(2), 34-50.

Alves, S. (2012). Ownership structure and earnings management: Evidence from Portugal. Australasian Accounting, Business and Finance Journal, Vol. 3(3).

Andri, Z., Muhammad, F. R., \& Khairuddin, N.B. M. Z. (2013). Power and likelihood of financial statement fraud: Evidence from Indonesia. Journal of Advanced Management Science, Vol. 1, No. 4.

Bala, H., \& Ibrahim, I. (2016). Monitoring characteristics and financial reporting quality of listed conglomerates firms in Nigeria. Journal of Accounting Research and Practice, Vol. 3, No. 2.

Barclay, M. J., \& Holderness, C. G. (1991). Negotiated block trades and corporate control. Journal of finance, $25,861-878$

Beneish, M. D. (2001). Earnings management: A perspective. Managerial Finance, 27(12), pp.3-17.

Beasley, M.S. (1996). Empirical analysis of the relation between the board of director composition and financial statement fraud. The Accounting Review, Vol 6(7)

Beuselinck, C., Belen, B., \& Juan, M. G. L. (2013). The role of foreign shareholders in disciplining financial reporting. Working paper Series. 


\section{International Journal of Social Science and Economic Research}

ISSN: 2455-8834

Volume:05, Issue:10 "October 2020"

Bushee, B. (2001). Do institutional investors prefer near-term earnings over long-run value? Contemporary Accounting Research, 18(2), 207-246.

Bushman, R. M., \& Smith, A. J. (2003). Transparency, financial accounting information, and corporate governance. Economic Policy Review, Vol.9, No.1, pp65-87.

Carcello, J., Hermanson, D., \& Ye, Z. (2011). Corporate governance research in accounting and auditing: Insights, practice implications and future research directions. Auditing: A Journal of Practice \& Theory, Vol. 30, No. 30, pp. 1-31.

Chai, W., Hoogs, B.K., \& Verschueren, B.T. (2006). Fuzzy ranking of financial statements for fraud detection. Proceeding of International Conference on Fuzzy System. pp: 152- 158.

Chekili, S. (2012). Impact of some governance mechanisms on earnings management: An empirical validation within the Tunisian Market. Journal of Business Studies Quarterly. Vol 8(4)

Cheng, Q., \& Warfield, T. D. (2005). Equity incentives and earnings management. The Accounting Review, Vol.80, No.2, pp441-476.

Claessens, S., Djannklov, S., \& Lang, L. H. P. (2000). The separation of ownership and control in East Asian corporations. Journal of Financial Economics, Vol. 58, pp. 81- 112 .

Claessens, S., \& Fan, J. P. H. (2002). Corporate governance in Asia: A survey. International Review of Finance, 3(2), pp. 71-103.

Cohen, J., Krishnamoorthy, G., \& Wright, A. (2008). Form versus substances: The implications for auditing practice and research. Auditing: A Journal of Practice and Theory, Vol. 27, No. 2, pp. 181-198.

Cornett, M. M., Marcus, A. J., \& Tehraniam, H. (2008). Corporate governance and payfor- performance: The impact of earnings management, Journal of Financial Economics, Vol.87, No.2, pp357-375.

Cressey, D. (1953). Other people's money: A study in the social psychology of embezzlement. Glencoe, Illinois: The Free Press.

Dabor, E. L., \& Adeyemi, S. B. (2009). Corporate governance and the credibility of 


\section{International Journal of Social Science and Economic Research}

ISSN: 2455-8834

Volume:05, Issue:10 "October 2020"

financial statement. Journal of Business Systems, Governance and Ethic, 4,(1).

Daniel, T. H. M., \& Andhika, L. M. (2015). Analysis of factors that influence financial statement fraud in the perspective of fraud diamond. International Conference on Accounting Studies (ICAS) 2015.

Dechow, P. M., Sloan, R. G., \& Sweeney, A. P. (1996). Causes and consequences of earnings manipulations: An analysis of firms subject to enforcement actions by the SEC. Contemporary Accounting Research, Vol.13, No.1, pp1-36.

Donnelly, R., \& Lynch, C. (2002). The ownership structure of UK firms and the informativeness of accounting earnings. Accounting and Business Research, Vol.32,

Ebrahim, A. (2007). Earnings management and board activity: An additional evidence, Review of Accounting and Finance, Vol.6, No.1, pp42-58.

Fama, E., \& Jensen, M. (1983). Separation of ownership and control. Journal of Law and Economics, Vol. 26, pp. 301-325.

Fan, J., \& Wong, T. J. (2002). Corporate ownership structure and the informativeness of accounting earnings in East Asia. Journal of Accounting and Economics, Vol.33, pp401- 425 .

Hafiza, A. H., \& Susela, S. D. (2012). Institutional monitoring and earnings quality in Malaysia. International Congress on Interdisciplinary Business and Social Science, Vol 12(6)

Hamadi, M., \& Ines, G. (2011). Board independence and corporate fraud: The case of Tunisian firms. The Economic Research Forum, Vol 3(8)

Hamilton, D., I. \& Justin, M. O. G. (2012). Dimensions of fraud in Nigeria quoted firms. American Journal of Social and Management Sciences, Vol 6(7)

Ines, A., Anis, B.A., \& Anis, J. (2013). Detection of fraud in financial statements: French companies as a case study. International Journal of Academic Research in Accounting, Finance and Management Sciences, Vol. 3, No.3.

Iturriaga, F.J. L., \& Hoffmann, P. S. (2005). Earnings management and internal mechanisms of corporate governance: Empirical evidence from Chilean firms. Corporate Ownership \& Control, Vol.3, No.1, pp17-29. 
International Journal of Social Science and Economic Research

ISSN: 2455-8834

Volume:05, Issue:10 "October 2020"

Jennings, R. (1987). Unsystematic security price movements, management earnings forecasts, and revisions in consensus analyst earnings forecasts. Journal of Accounting Research, 25, 90-110.

Jensen, M. C., \& Meckling, W. H. (1976). Theory of the firm: Managerial behaviour, agency costs and ownership structure. Journal of Financial Economics, vol. 3, 305-306.

Joseph, V. C., \& Dana, R. H. (2008). Fraudulent financial reporting: How do we close the Knowledge Gap? Journal of Accounting Research, Vol 6(7).

Klein, A. (2002). Audit committee, board of director characteristics, and earnings management. Journal of Accounting and Economics, Vol.33, No.3, pp375-400.

Lalit, W., \& Virender, P. (2012). Forensic accounting and fraud examination in India. Internatio nal Journal of Applied Engineering Research, 7(11), 1-4.

La Porta, R. R., Lopez-de-slanes, F., Shleifer, A., \& Vishny, R. (1999). Corporate ownership around the world. Journal of finance, 54 471-518.

Luiss, L. (2010). The role of corporate governance in financial statement frauds. Barbara Sveva Magnanelli.

Manis, M., Dovalina, I., Avis, N.E., \& Cardoze, S. (1980). Base rates can affect individual predictions. Journal of Personality and Social Psychology, 38,231-248.

Morck, R., Shleifer, A., \& Vishny, R. W. (1988). Management ownership and market valuation: An empirical analysis. Journal of Financial Economics, Vol.20, No.1-2, pp293-315.

Muntari, M. (2015). Detecting corporate fraud and financial distress using the Altman and Beneish models. International Journal of Economics, Commerce and Management United Kingdom, Vol. III, Issue 1.

Rezaee, Z. (2002). Causes, consequences and deterrence of financial statement fraud. Perspectives on Accounting Critical, 16.pp 277-298.

Riadi, A. D. R., \& Mita, A. F. (2018). The Effect of Ownership Structure on a Company’s Tunneling Activities: Indonesian Evidence. Advances in Economics, Business and Management Research, 8(1) 


\section{International Journal of Social Science and Economic Research}

ISSN: 2455-8834

Volume:05, Issue:10 "October 2020"

Salsiah, M.A., Mohamat, S.H., \& Norman, M.S. (2007). Block-ownership and earnings management in Malaysian listed firms. Corporate ownership \& control, Vol. 5(1.)

Senmila, P.A., \& Elijah, A. (2012). Earnings management and ownership structure: Evidence from Nigeria. Research Journal of Finance and Accounting, Vol 6(7).

Shleifer, A. \& Vishny, R. W. (1997). A survey of corporate governance. Journal of Finance, Vol.52, No.2, pp737-783.

Skousen, C., \& Wright, C. (2006). Contemporaneous risk factors and the prediction of financial statement fraud, working paper, department of accounting university of Texas at Arlington.

Spathis, C. (2002). Detecting false financial statements using published data: Some evidence from Greece. Managerial Auditing Journal, Vol. 17, No. 4, pp. 179-191.

Srivastava, A. (2011). Ownership structure and corporate performance: Evidence from India. International Journal of Humanities and Social Science, Vol. 1 No. 1.

Tarjo, T. \& Nurul, H. (2015). Application of Beneish M-Score models and data mining to detect financial fraud. 2nd Global Conference on Business and Social Science.

Teshima, N., \& Shuto, A. (2008): Managerial ownership and earnings management: Theory and Empirical Evidence from Japan. Journal of International Financial Management and Accounting, 19(2): 107-132.

Waidi, K. A., \& Johnson, K.O. (2016). Ownership structure and the quality of financial reporting: Evidence from Nigerian deposit money banks. International Journal of Economics, Commerce and Management United Kingdom. Vol 7(1)

Warfield, T. D., Wild, J. J., \& Wild, K. L. (1995). Managerial ownership accounting choices, and informativeness of earnings. Journal of Accounting and Economics, Vol.20, pp61-91.

Yeo, H. (2012). Impacts of the board of directors and ownership structure on consolidation strategies in shipping industry. The Asian Journal of shipping and logistics Volume 8.

Zhong, K., Donald, W., \& Zheng, X. (2007). The effect of monitoring by outside blockholders on earnings management. Quarterly Journal of Business and Economics, 46, pp. 38-60. 